\title{
河川流出量分析による浸透能の検出について
}

$$
\text { 正員 酒 茾 - 郎* }
$$

\section{LIMIT OF INFILTRATION FROM RUN-OFF RECORDS}

\author{
By Ichiro Sakai, C.E. Member
}

Synopsis : Applying the specific base flow curve of a stream run-off, we can devide the run-off into two parts precisely, one the base flow and another the surface flow. In this way, we are able to estimate the rate of precipitation, which causes the surface flow, and the remainder as the "limit of infiltration", from rainfall records.

要 旨 河川特有の基底流減衰曲線を適用することによつて, 降雨時の河川流出量を表面流々基底流々飞, かなりの精度で分離することができる。これを利用して, 分離した表面流、対応する水量を降雨中から求め ることが可能であり，したがつてとの残余が浸透能の数值を知ることができる。

\section{1.まえがき}

洪水計算飞括いて，直接流出の原因となる降水量を求めるに当り，地下浸透する水量をさ乙引か水ばならな いが，従来浸透の限界となる浸透能を実績から検出したものはないようである。

本文でほ先に報告した河川特有の基底流減衰曲線を使用すれば，表面流と基底流とを，かなり精密に分離する ことができるので，現場と秘子る測水記録を分析して，浸透能を求め得ることを提案する。

\section{2. 河川特有の基底流減衰曲線}

河川の流出を, 地下水の浸出以よるいわゆる基底流と，地下に浸透することなく直接流出する表面流と分け て考学るとき，前報告に述べたように，地下水量と基底流との間飞１対１の対応がある。このことはとの後る引 き続き確認している所であつて，実に㛜重飞守られている。この関係を示す基底流減衰曲線 (BF 曲線) は, 本 文に述べようとする浸透能算出飞る，との規矩となるもので，この分野の基礎となる重要法則であるから，恋ず との概要を述べる。

河川流域に彩いて，地下水の貯溜される容器は，模型的飞図一1の上万に，槽の 中に土砂なぞを充填し，側面飞水の浸出を可能ならしめる小孔を多数設けたるのと 考光ることができる。容器内の水位が高いとき流出が多く，水位が低くなると流 出が減少することは，当然考光られるところである。このような小槽をあるいは高

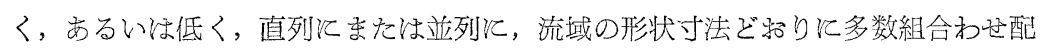

図一1 河川模型

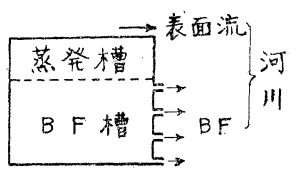
置したものが実際の流域乞のるのである。かく考光られる流域小槽群のうち1個を単位槽として取りあげて考察 するに, 各小孔からの流出は時間経過飞つれて指数関数近い形で減哀すると考光られ，また，上部の小孔から の流出は急速に減衰し，下部になるほど減衰が緩慢となることる，常識的に受け入れられるとこるである(実験 により確かめることも容易である）。このように考光てくると，これら単位槽の集合である流域とのものの流出 が，上記水位 (従つて包蔵水量) 飞応じて，減衰しながら流出するという本質を失うと情考克られないので，そ の様相を流域の 1 地点飞関し調查して得たのが, BF 曲線である(表一1)。

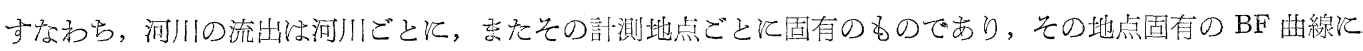
沿うて減衰する。降雨があれば，その量応じて基底流は増加し，1時いくらかの表面流をともなうが，表面流

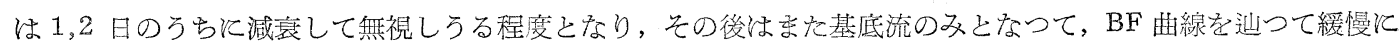
減衰する。BF 曲線については，多少は孛節的変化を感じられるが，か九がい期間，洪水期間を通じて，かなり

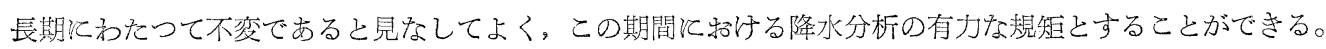

\section{3. 流域の空げきについて}

前報告で核，上記模型を上下に区分して，流出に関係なく蒸発すべき水を貯溜する部分（蒸発槽）と，基底流 用の水のみを眝溜する部分（BF 槽）と飞分けて考兄，これら雨槽の空げき分を“洪水予防ポケット”とし，洪 
表一1 基 底 流減衰衰旭川第一ダム

\begin{tabular}{|c|c|c|c|c|c|c|}
\hline $\mathrm{BF}$ 番号 & BF 流量 & $\begin{array}{c}\text { BF 槽 } \\
\text { 保有水量 }\end{array}$ & BF 槽空げき & 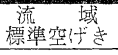 & $\begin{array}{l}\text { 同 左 } \\
\text { 換算雨量 }\end{array}$ & 記 \\
\hline 0 & 85 & 800 & 0 & 0 & 0 & \multirow{4}{*}{  } \\
\hline $\begin{array}{l}1 \\
2 \\
3 \\
4 \\
5\end{array}$ & $\begin{array}{l}70 \\
60 \\
53 \\
47 \\
41\end{array}$ & $\begin{array}{l}715 \\
645 \\
585 \\
532 \\
485\end{array}$ & $\begin{array}{r}85 \\
155 \\
215 \\
268 \\
315\end{array}$ & $\begin{array}{l}145 \\
264 \\
366 \\
456 \\
536\end{array}$ & $\begin{array}{l}11 \\
20 \\
28 \\
35 \\
41\end{array}$ & \\
\hline $\begin{array}{r}6 \\
7 \\
8 \\
9 \\
10\end{array}$ & $\begin{array}{l}36 \\
32 \\
28 \\
25 \\
23\end{array}$ & $\begin{array}{l}444 \\
408 \\
376 \\
348 \\
323\end{array}$ & $\begin{array}{l}356 \\
392 \\
424 \\
452 \\
477\end{array}$ & $\begin{array}{l}605 \\
666 \\
721 \\
768 \\
811\end{array}$ & $\begin{array}{l}46 \\
50 \\
55 \\
58 \\
61\end{array}$ & \\
\hline $\begin{array}{l}11 \\
12 \\
13 \\
14 \\
15\end{array}$ & $\begin{array}{l}20 \\
18 \\
17 \\
15 \\
14\end{array}$ & $\begin{array}{l}300 \\
280 \\
262 \\
245 \\
230\end{array}$ & $\begin{array}{l}500 \\
520 \\
538 \\
555 \\
570\end{array}$ & $\begin{array}{l}850 \\
884 \\
915 \\
944 \\
969\end{array}$ & $\begin{array}{l}64 \\
67 \\
69 \\
71 \\
73\end{array}$ & \\
\hline $\begin{array}{l}16 \\
17 \\
18 \\
19 \\
20\end{array}$ & $\begin{array}{l}13 \\
12 \\
11 \\
10.4 \\
9.8\end{array}$ & $\begin{array}{l}216 \\
203 \\
191 \\
180 \\
169.6\end{array}$ & $\begin{array}{l}584 \\
597 \\
609 \\
620 \\
630.4\end{array}$ & $\begin{array}{r}993 \\
1015 \\
1035 \\
1054 \\
1072\end{array}$ & $\begin{array}{l}75 \\
77 \\
78 \\
80 \\
81\end{array}$ & \multirow{2}{*}{ 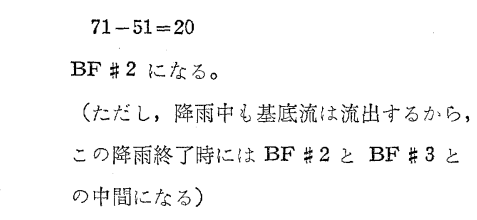 } \\
\hline $\begin{array}{l}21 \\
22 \\
23 \\
24 \\
25\end{array}$ & $\begin{array}{l}9.2 \\
8.6 \\
8.2 \\
7.9 \\
7.6\end{array}$ & $\begin{array}{l}159.8 \\
150.6 \\
142.0 \\
133.7 \\
125.8\end{array}$ & $\begin{array}{l}640.2 \\
649.4 \\
658.0 \\
666.3 \\
674.2\end{array}$ & $\begin{array}{ll}1 & 088 \\
1 & 105 \\
1 & 119 \\
1 & 133 \\
1 & 146\end{array}$ & $\begin{array}{l}82 \\
84 \\
85 \\
86 \\
87\end{array}$ & \\
\hline $\begin{array}{l}26 \\
27 \\
28 \\
29 \\
30\end{array}$ & $\begin{array}{l}7.3 \\
7.0 \\
6.7 \\
6.5 \\
6.2 \\
\end{array}$ & $\begin{array}{r}118.2 \\
110.9 \\
103.9 \\
97.2 \\
90.7\end{array}$ & $\begin{array}{l}181.8 \\
689.1 \\
696.1 \\
702.8 \\
709.3\end{array}$ & $\begin{array}{ll}1 & 159 \\
1 & 171 \\
1 & 183 \\
1 & 195 \\
1 & 206\end{array}$ & $\begin{array}{l}88 \\
89 \\
90 \\
91 \\
91\end{array}$ & $\begin{array}{l}\text { 註 } 4: \text { 流域面積 } 1140 \mathrm{~km}^{2} \\
\quad \therefore \text { 雨量 } 1 \mathrm{~mm}=13.2 \text { 個日 }\end{array}$ \\
\hline $\begin{array}{l}31 \\
32 \\
33 \\
34 \\
35\end{array}$ & $\begin{array}{l}6.0 \\
5.7 \\
5.6 \\
5.5 \\
5.4\end{array}$ & $\begin{array}{l}84.5 \\
78.5 \\
72.8 \\
67.2 \\
61.7\end{array}$ & $\begin{array}{l}715.5 \\
721.5 \\
727.2 \\
732.8 \\
738.3\end{array}$ & $\begin{array}{l}1216 \\
1226 \\
1236 \\
1246 \\
1225\end{array}$ & $\begin{array}{l}92 \\
93 \\
94 \\
94 \\
95\end{array}$ & \\
\hline $\begin{array}{l}36 \\
37 \\
38 \\
39 \\
40\end{array}$ & $\begin{array}{l}5.2 \\
5.1 \\
5.0 \\
4.9 \\
4.8\end{array}$ & $\begin{array}{l}56.3 \\
51.1 \\
46.0 \\
41.0 \\
36.1\end{array}$ & $\begin{array}{l}743.7 \\
748.9 \\
754.0 \\
759.0 \\
763.9\end{array}$ & $\begin{array}{ll}1 & 264 \\
1 & 273 \\
1 & 282 \\
1 & 290 \\
1 & 298\end{array}$ & $\begin{array}{l}96 \\
96 \\
97 \\
98 \\
98\end{array}$ & \\
\hline $\begin{array}{l}41 \\
42 \\
43 \\
44 \\
45\end{array}$ & $\begin{array}{l}4.7 \\
4.6 \\
4.5 \\
4.5 \\
4.4\end{array}$ & $\begin{array}{l}31.3 \\
26.6 \\
22.0 \\
17.5 \\
13.0\end{array}$ & $\begin{array}{l}768.7 \\
773.4 \\
778.0 \\
782.5 \\
787.0\end{array}$ & $\begin{array}{l}1307 \\
1315 \\
1323 \\
1330 \\
1338\end{array}$ & $\begin{array}{r}99 \\
99 \\
100 \\
101 \\
101\end{array}$ & \\
\hline $\begin{array}{l}46 \\
47 \\
48\end{array}$ & $\begin{array}{l}4.3 \\
4.3 \\
4.2\end{array}$ & $\begin{array}{l}8.6 \\
4.3 \\
0\end{array}$ & $\begin{array}{l}791.4 \\
795.7 \\
800.0\end{array}$ & $\begin{array}{l}1345 \\
1353 \\
1360\end{array}$ & $\begin{array}{l}102 \\
102 \\
103\end{array}$ & \\
\hline
\end{tabular}

水計算飞当つては，降雨から洪水予防ポケット分だけ空除したるのが，直接流出の原因となると述べたのである が，小洪水はこれら両槽を埋めつくさないうちに終了することがあるので，次のよう亿改めたい。

すなわち，降雨はこれら雨槽の空げきを，浸透能の範围内に特いて埋めていき，それ消費せられる雨量がい わゆる損失雨量である。

また用語についても，“洪水予防ポケット”と称えたるのを“流域の空げき”と呼ぶことに改めたい。

\section{(1) BF 槽の空げき}

$\mathrm{BF}$ 槽からの流出 $\mathrm{BF}$ は, この槽の貯水量によつて決定せられ，その関係はかなり笽格に守られているので，

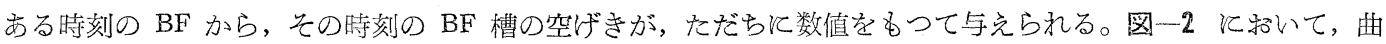
線 $b_{1}$ は BF 曲線であるとする。BF番号 $t_{1}$ のとき(この時の BF は線分 $t_{1} B_{1}$ で表わされる) $\mathrm{BF}$ 槽の空げき は $0 t_{1} B_{1} B_{0}$ で国香れた面積で表わされる。したがつてこの面積はとの時の BF (貯水池流入量) が index とな つて，ただち擞值をるつて与兄られる（あらかじめ数表をつくることすできる）。

\section{(2) 蒸発槽の空げき}

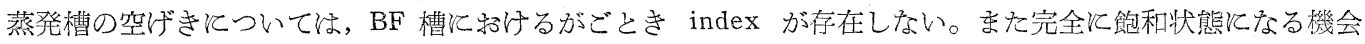
もきわめてまれである(しばしば飽和するならば, その時を起点として, その後の蒸発状沉を推定して, 空げき 容積の概略を知るこることができる)。

推定の一つの便法として，BF 曲線を用いて䅂こなう降水分析の統計から，BF 槽の空げきに対する一定比率 
（われわれの場合70\%）を求めることができる。ただし， この関係は平均值としては，かなり正確であるが，1回ご との比率については, との直前の降雨や蒸発の䧗歴の相違 飞よつて，多少のくるいは末好れなと思われる。

降雨や日照蕧歴などによつて，いかなる補正を要するか は今後の研究にまつとととし，本質的にはこれら雨槽の空 げきは正比例すべき性質を有するから，ここでは一定比率 (旭川については BF 槽空げきの70\% が蒸発槽の空げき である)として取扱う。

\section{4. 損 失雨量}

損失雨量とは，流域の空げきを充填するためと消費せら れて, 直接流出とならない雨量のことである。本文で提案 するところは，流域の空げきがBFを index として，大体

図一2 降水分析図

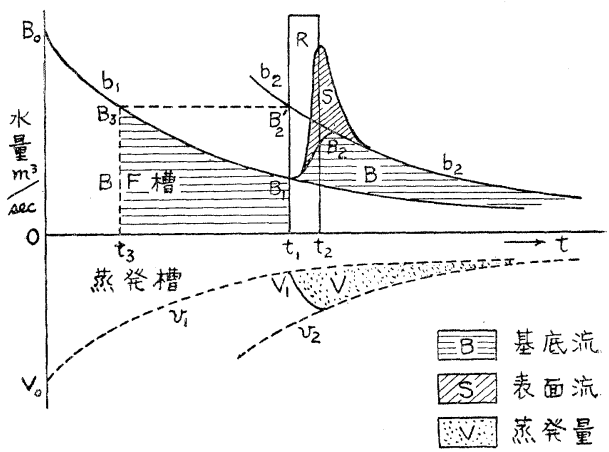

$t_{1}$ における $b_{2}$ 曲線の值 $\left(B_{2}{ }^{\prime}\right)$ を

$b_{1}$ 曲線上に求めこ机を $B_{3}$ とする

数值をるつて与兄られ，浸透能の範囲内の雨量が，この空げきを逐次充媜していくものであるとと，また浸透能

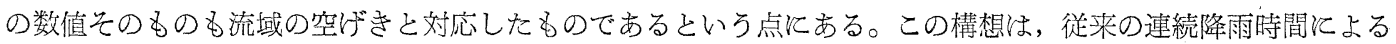
浸透能の減衰あるいは累加雨量江対する累加損失雨量などの考光方の工程で起きる不具合を解消する。

\section{5. 漫 透 能}

浸透能が流域の湿潤状態関係することは明らかであつて, 前記模型のごとく考党ると, 蒸発槽拈よび BF 槽 が飽和状態のとき, 浸透能は雨槽からの放出を補なうと止るるから, きわめて小さい（旭川の例では BF 0 番を 維持するための $0.27 \mathrm{~mm} / \mathrm{hr}$ V, 降雨中の蒝発量を加光たるの)。

一方流域が乾燥状態 (BF 番号大) の場合とは, かなりの降雨でも, よく両槽に浸透する。降雨と流出とのバ ランス シートルよれば, BF 19 番では $6 \mathrm{~mm} / \mathrm{hr}$ の降雨が注とんど表面流をともなつていないから，その程度 までは浸透しうることがわかる。

このように浸透能は流域の湿潤状態によつて大いに異なるのであるから，なんらかの方法にょつて，その状況 そ到達する末での履歷を折り込んだものから出発しなければならない。従来, それふでの降雨継続時間によると

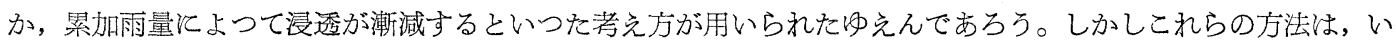
ずれる雨量強度の影響, あるいはいつまで溯つて降雨時間をとるかという難点, さらに, とのようにある時間溯 つて考光たとしても，その考光の出発点の状況に差別があつた場合，それをいかに反映させるかなど，不具合な 点があつて，明快な解決は得られないと思う。

本文では，これらを一挙と解決する方法として，流域の状況はBF 番号によつて一義的に定義されているとい う若え方を提案するるのである。

\section{(1) 降雨分析による漫透能の判定}

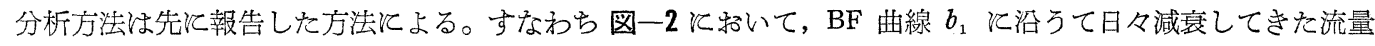
が，降雨 $R$ のために增加し， $\mathrm{BF}$ 曲線 $b_{2}$ 亿移動したとする。移動の過渡期に生じた表面流は面積 $S$ で表わされ る。 $\mathrm{BF}$ 槽飞供給された水量 $B$ は

$B$ 二面積 $t_{3} B_{3} B_{1} t_{1} t_{3}$ 一面積 $B_{1} B_{2}{ }^{\prime} B_{2} B_{1}$ である。このとき水量とついて恒等式

$R=B+V+S \cdots \cdots V$ 屿蒸発槽㲸充填された水量, が成り立つことは前報告で述べたと特りである。

すし $S$ がR の1\%以下であるならば, その降雨は全く表面流をつくらなかつたす木なわちととでとく浸透し たことを事実上証明するすのである(1\%というのは，いかなる微雨です直接流出となる比率，すなわち河川流 水の表面積の，全流域面積注対する割合である)。

ま九，む乙表面流 $S$ が $1 \%$ を超克て生じるならぼ，降雨 $R$ のうち，それだけ浸透しないすのがあつたといろ ことである。降雨波形が，たとえば図一3 と扮ける $R_{1}$ のごとく，その未尾強度の強いるのを有する場合は， その尖端に数ける $S$ と等面積の部分が表面流 $S$ の原因になつたことが明らかであつて，同時にとれ以下の部分 はことごとく浸透したと考党ざるを得ない。

降雨波形が図一3のR のどとく，降り初めのとき強度が強い場合は，いずれの部分が $S$ の原因となつたか明 らか、はしがたい。この場合ある減衰曲線 $f$ で切り，その上方の面積 $S$ が等しくなるようにすれば，この部分 
が浸透しなかつたと推定できるが（この曲線 $f$ は後述の浸透能曲線から逆算しう る)このような不明確な点は除いても, 多くの降雨例の中には, 極端な突出部分が ある場合，あるい最終降雨が特汇大きいるのなど表面流の原因となる部分が明ら かなるのがあるので, これらのみとりあげることとよつて, 明確に浸透能の限界を つかむことができる。要するに BF 曲線が相当正磪であるから, 表面流と BF の分

図一3 降雨型

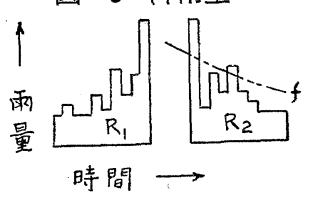
離が正確浪実施され，したがつて降雨拉よび流量測定の記録から，実際々あらわれ た浸透能を分離することが可能である。

\section{(2) 漫透能の実例}

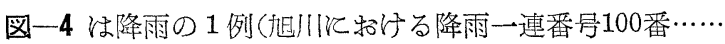
昭和33年 4 月）から浸透能を求めたもので, 実線は貯水池へ の流入量実測值（上流湯原発電所の影響をさし引いたもの）， 破線は基準として用いた BF 曲線である。BFが 17 日飞 10 番 (1 日平均 $23 \mathrm{~m}^{3} / \mathrm{sec}$ ) であつたこと柱，それまでの実績か ら，また 18 日に 5 番洺つたことは 20 日以降の実績を溯つ て延長することから明らかである。不明確な点は BF が転移 するとき，たどる経路が，イとなるか口となるか，あるいは その中間であるかという点のみである。しかもイと口との差 は僅少であるから，表面流の量は斜線で示される量あるいは

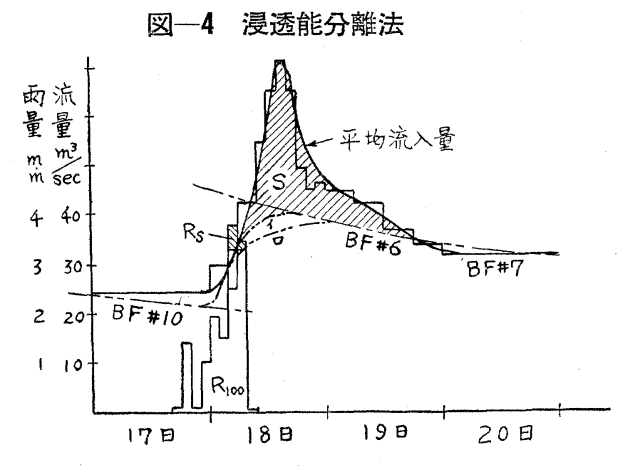

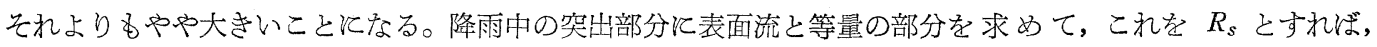
$R_{s}$ が表面流の原因となつたことが明らかである。したがつてこの場合， BF が 5 番澾する原因が完了する直 前まで, $3.3 \mathrm{~mm} / \mathrm{hr}$ 程度の降雨が流域江括いて浸透したといろ一つの実績を得たわけである（もしとれ以前の降 雨が多少とも表面流の原因となつたと見るならば, 実績の表面流は不変であるから,降雨の突出部分の $R_{s}$ はとれ だけ減じて考党なければならないので, 降雨初期低い雨量強度から表面流を生じ降雨終期に挍いて $3.3 \mathrm{~mm} / \mathrm{hr}$ 以上る浸透し得たという不合理におちいる)。

(3) 浸透能曲 線

前項のようとして得て点を多数プロットして, 旭川第一ダム地点と括ける流域浸透能曲線を得た。これを図一 5 と示す。この図では BF 番号相当の標準空げき（BF 槽空げきの 1.7 倍を全空げきと見なす）を，全流域面積注対する雨量 (mm) 飞換算して横座標にとつてある。

点のバラツキのおもな原因は，降雨が全域汶して均等でない場 合があること，特よび繁発槽の空げきが標準值からずれていること

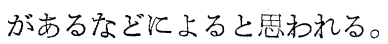

本資料作製江当つて, 降雨は各測点の記録のうち, 代表点のもの を用いるべきであつて,平均值を用いてはならない。たと齐ば 図一 6 のごとくA地点についてはその降雨中 $a か ゙$, 地点飞ついてはその降雨中 $b$ が，それぞれの区域の表面流の原因とな つたと見るべきである。本図資料として は旭川第一ダム地点の降雨曲線を用い, かつ同一降雨が流域各測点 (8地点) 飞

\section{図一6 降雨形}

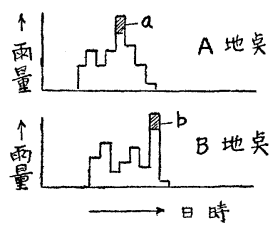

関して, ほぼ等量であつた場合のみを採 用した。

\section{6. 浸透能曲線の使用方法}

この浸透能曲線は流域の空げき (降雨量換算) 飞対応して求めて あり, 流域の空げきはれた BF そ対応させてあるから, 考察時の BF から,ただち飞初めの浸透能が得られる。図一下 亿扔いて, $i$ は浸透能曲線である。 $\mathrm{BF}$ 番号 $n$, したがつて流域の空げき $p_{1} の$ とき降雨が初まつたとする。最初の浸透能 $i_{1}$ は曲線 $i$ からただち

\section{図一5 漫透能曲線}

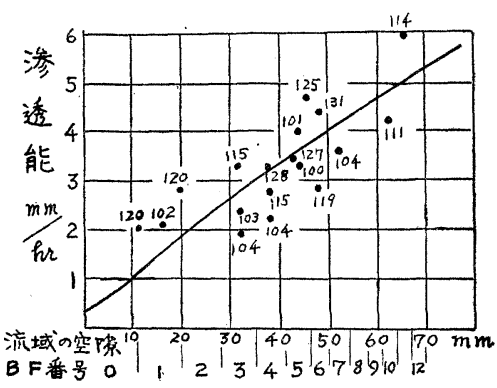

【説明】流域の空げきは全域平均雨量に換算し てある。流域面積 $1140 \mathrm{~km}^{2}$ のえ $1 \mathrm{~mm}$ 雨 量が 132 個日に相当する。罒表中の数字は降雨 に付した一連番号である.

\section{図-7 損失雨量の求め方}

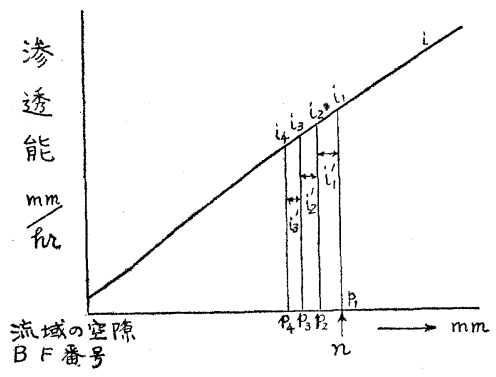


飞得られる。

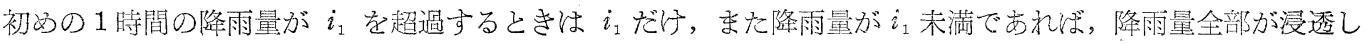
て, 流域の空げきを埋めるから, 空げきはそれだけ小さくなる。乙たがつて 2 時閒目の浸透能は, 初めの 1 時間

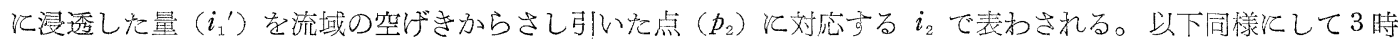

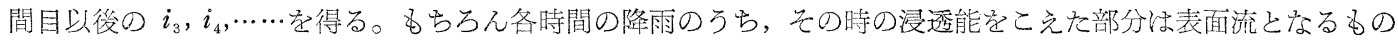
である。

この方法によつて得た有効雨量から直接流出を求め, これに基底流（浸透によつて増加したもの）を加光るこ とによつて, 洪水予想計算を実用上交障のない程度に行うことができる。このことについては別稿定すつて報告 する。

\section{7. 結言}

浸透能は流域の湿潤状沉に大きく左右される。この計算に当つて, 從来, 初期条件として無降雨継続時間をと りあげたるのなどがあるゆ元んであるう。しかし，これは条件の一部であつて全部の条件をとり入れたものでは ない。筆者は, 河川流出量の刻々の数值乞のものこそ, その時までのあらゆる履歴を総括した最善の index で あることを強調するものである。

流出量を利用することの効果を，実用的に発揮するための定規として，先に，河川特有の基底流減衰曲線を提 唱したのであるが，本文では，浸透能に関しても，同じ定規を用いて表面流との分離を行うならね゙，ての数值を 実績值として把握できることを述べた。

ただ残念なことは, 適用した流域について降雨記録が少く（流域面積 $1140 \mathrm{~km}^{2}$ 亿対して 8 点）, 毎時間雨量 の記録はさらに少く ( 5 点) ために, 総降水量捛よび最大時間雨量に対して不安があることである。この点将来 早急整備して，さらに完全な数值をたしかめることに努力する決意であるが，今まで得た結果のみによつて る，実用上十分の効果があり，治水祘よび給電上大いに役立つている。広く一般に利用せられることを熱望する るのである。 